Aquaculture Research

November 2017, Volume 48, Issue 11, Pages 5463-5471

http://dx.doi.org/10.1111/are.13361

http://archimer.ifremer.fr/doc/00384/49508/

(C) 2017 John Wiley \& Sons Ltd

\title{
Effects of hydrodynamic factors on Pecten maximus larval development
}

\author{
Holbach Marine ${ }^{1,2,{ }^{*}}$, Robert Rene ${ }^{3}$, Miner Philippe ${ }^{2}$, Mingant Christian ${ }^{2}$, Boudry Pierre ${ }^{2}$, \\ Tremblay Réjean ${ }^{1}$
}

${ }^{1}$ Institut des Sciences de la Mer; Université du Québec à Rimouski; Rimouski QC ,Canada

${ }^{2}$ Laboratoire des Sciences de I'Environnement Marin (LEMAR UMR 6539 UBO/CNRS/IRD/Ifremer);

Centre Bretagne; Ifremer; Plouzané ,France

${ }^{3}$ Unité Littoral; Centre Bretagne; Ifremer; Plouzané, France

*Corresponding author : Marine Holbach, email address : holbach.marine@gmail.com

\begin{abstract}
:
Hatchery production of great scallop, Pecten maximus, remains unpredictable, notably due to poor larval survival. Large-scale flow-through systems up to $3500 \mathrm{~L}$ have been developed to avoid the use of antibiotics in static systems. Alternatively, small-scale flow-through systems have been successfully applied for oysters but they proved to be unsuitable to rear scallop larvae. By focusing on physical factors presumed to limit P. maximus larval development, this study aimed to optimize great scallop larvae rearing parameters under controlled conditions. First, the influence of aeration on larval performances, energetic metabolism and antioxidant defences were studied both in static and flowthrough systems. Aeration depressed larval food intake, regardless of the intensities of flow tested $(100 \mathrm{ml} / \mathrm{min}, 155 \mathrm{ml} / \mathrm{min}$ and $270 \mathrm{ml} / \mathrm{min})$. On the other hand, antioxidant enzyme activities remained constant or decreased, suggesting that antioxidant defences were inactivated. The increase in citrate synthase activity suggested an increase in metabolic rate possibly due to a turbulent stressful environment. All larvae exposed to such turbulence died before reaching metamorphosis, whereas those reared without aeration survived well $(\approx 95 \%)$. The effects of water renewal were thereafter studied in 50-L flow-through flat-bottomed tanks. No differences in survival $(20.4 \pm 0.5 \%)$, growth $(3.8 \pm 0.2 \mu \mathrm{m} / \mathrm{d})$, competence $(5.6 \pm 0.2 \%)$, energetic metabolism level and antioxidant enzyme activities were observed when comparing 12.5 and $25 \mathrm{~L} / \mathrm{hr}$ water renewal. Whereas air bubbling leads to detrimental effects, flow-through in small flat-bottomed tanks appears to be a suitable technique for scallop larvae rearing.
\end{abstract}

Keywords : aeration, flow-through, larval physiology, Pecten maximus 


\section{Introduction}

Since the 1960's, worldwide scallop production rose from 100000 to 2.6 million tones, mostly related to aquaculture industry responsible for $71.4 \%$ of the total production (FAO 2013). First attempts at scallop aquaculture production were realised in Japan with the use of wild juveniles obtained on artificial collectors for population enhancement and sea-ranching. However, development of hatchery-based production of juveniles was rapidly needed to avoid seasonal fluctuations (Buestel 1979). After first laboratory trials in the early 1970's (Gruffydd \& Beaumont 1972), hatchery production of scallops using static systems (with a complete seawater renewal every 2 days) was rapidly established in several countries, including France (Robert \& Gérard 1999), Norway (Bergh \& Strand 2001), USA (Widman, Choromanski, Robohm, Stiles, Wikfors \& Calabrese 2001) and Chile (Brokordt, Núñez \& Gaymer 2011), but success of hatchery production remained unpredictable due to important larval survival variability (see Andersen, Christophersen \& Magnesen (2011) for review). Use of preventive antibiotics stabilize the productivity, but large-scale flow-through systems up to $3500 \mathrm{~L}$ have been previously developed to prevent the unsustainable use of chemical products. In such systems, both algae and water are continuously added, thus leading to a more stable environment. Results are promising but this system needs to be optimized, as relatively low larval yield (6.9\%) and densities (3 larvae $\mathrm{ml}^{-1}$ ) still limit commercial extension of such systems (Andersen, Christophersen \& Magnesen 2012). A newly designed small-scale flow-through system maintaining a high larval density of up to 300 larvae $\mathrm{ml}^{-1}$ supports survival rates $>70 \%$ of oyster larvae (Crassostrea gigas and Ostrea edulis) until metamorphosis (da Costa, Petton, Mingant, Bougaran, Rouxel, Quéré, Wikfors, Soudant \& Robert 2015; Robert, Vignier \& Petton 2017;). Unfortunately these were unsuccessul for Pecten maximus, as larvae did not survive beyond 6 days post-fertilization (dpf) of rearing with a maximum density of only 10 larvae $\mathrm{ml}^{-1}$ (Holbach 2015). In these 5-L cylindrical shaped 
tanks (104 cm height and $9 \mathrm{~cm}$ diameter) seawater recirculation $\left(100 \%\right.$ renewal $\left.\mathrm{h}^{-1}\right)$ maintain the quality of larval environment; while, aeration allowed homogenization of food and larvae in the water column. Tolerance of bivalve larvae to stressful factors is species specific (Calabrese \& Davis 1970) and pectinid larvae are known to be highly sensitive compared to oysters or clams (Robert \& Gérard 1999; Helm, Bourne \& Lovatelli 2004). Understanding the effects of physical parameters on pectinid larval development is therefore a prerequisite to determine optimal rearing parameters leading to reliable production of juvenile great scallops.

In the present study, we hypothesized that turbulence related to the high water aeration or high water renewal might be detrimental for the development of scallop larvae. The first objective was to determine the effects of aeration on growth, survival, microalgae consumption and physiological status of $P$. maximus larvae reared, in batch, in low volume flat-bottom tank. Vibrio development was concomitantly surveyed. The second objective examined the potential of flat-bottom tanks for $P$. maximus larval rearing by the use of a $50 \mathrm{~L}$ prototype flow-through system in which the combined effects of water renewal and aeration on growth, survival, competence to metamorphosis and physiological status of scallop larvae were performed. Vibrio load evolution was similarly assessed. Activities of several enzymes have been shown to be good indicators of the physiological status of bivalve larvae (Genard, Larouche, Nicolas, Miner, Beaudin \& Tremblay 2014; Genard, Pernet, Lemarchand, Boudry, Moraga \& Tremblay 2011). Some of those associated with larval performances results were accordingly used to estimate the effects of physical rearing conditions on P. maximus larval condition and stress level. Citrate synthase (CS) is a key enzyme in the formation of adenosine triphosphate (ATP) and a good indicator of energetic metabolism (Moran \& Manahan 2003) while catalase (CAT) and superoxide dismutase (SOD), two antioxidant enzymes, were recorded as indicators of oxidative stress (Genard et al. 2011 ; Philipp, Schmidt, Gsottbauer, Sanger \& Abele 2008). 


\section{Materials and Methods}

\section{Common variables between experiments}

To understand the effects of hydrodynamic factors on pectinid larval development, some common general variables were measured: mortality, growth, physiological status estimated by the total protein amount and enzymatic activity of CAT, SOD and CS and the percentage of Vibrio in total larval flora. The first experiment determined the effects of aeration and was realized in batch. The second experiment on the impact of the water flow was based on flowthrough system with continuous addition of food. Algal consumption was not determined because it was technically difficult to access in such prototype and considered for a first assay as not crucial informative. In contrast, another variable was taken into account, the competence to metamorphosis to achieve a better knowledge of $P$. maximus development and the potentiality of $50 \mathrm{~L}$ rectangular flat bottom flow-through tanks.

\section{Aeration as a potential source of stress}

Two dpf old D-larvae, originating from a commercial scallop hatchery (Tinduff, Finistère, France), were transferred to Ifremer's experimental facilities (Argenton, Finistère, France). Up to $11 \mathrm{dpf}$, larvae were reared in 150-L cylinder-cone shape tanks. During this period, a single 2-day preventive chloramphenicol treatment, at $8 \mathrm{ppm}$, was applied from 2 to $4 \mathrm{dpf}$. At $11 \mathrm{dpf}$, they were retained on a $100-\mu \mathrm{m}$ mesh sieve and transferred to 5-L flat-bottomed beakers. Thus, the largest and strongest individuals known to be more resistant (Kesarcodi-Watson, Miner, Nicolas, Asmani \& Robert 2014) were selected while smaller larvae were discarded. During the larval cycle, larvae were collected each two days on a $45 \mu \mathrm{m}$ mesh, suspended and homogenized in 1 $\mu \mathrm{m}$-filtered and UV-treated seawater at $19^{\circ} \mathrm{C}$, as described by Helm, Bourne \& Lovatelli (2004), for estimation of mortality and growth. Larvae were reared at a density of $10 \mathrm{ml}^{-1}$ and fed two flagellates, Pavlova lutheri and Tisochrysis lutea plus one diatom, Skeletonema marinoi to ensure 
60 cells $\mu 1^{-1}$ available each day (20/20/20 equivalent cell volume) over the whole experiment. This diet has been demonstrated to support optimal growth and over $80 \%$ survival on complete larval rearing of P. maximus (Tremblay, Cartier, Miner, Pernet, Quéré, Moal, Muzellec, Mazuret, Samain 2007). To avoid algae deposition, each beaker was gently hand mixed twice a day. On 13 dpf, four aeration conditions were applied $(n=3)$ : no aeration (control: 0$)$, low aeration $\left(100 \mathrm{ml} \mathrm{min}^{-1}\right)$, medium aeration $\left(155 \mathrm{ml} \mathrm{min}^{-1}\right)$ and high aeration $\left(270 \mathrm{ml} \mathrm{min}^{-1}\right)$. Aeration was provided by a $100 \mathrm{kPa}$ blower coupled to a dehumidifier and $0.1 \mu \mathrm{m}$ filtered before delivering in each tank with one glass pipette of $1 \mathrm{ml}$ having an aperture of $0.9 \mathrm{~mm}$. Larvae were reared without any antibiotic until the end of the experiment when they reached the pediveliger stage ( 25 dpf). The lowest aeration supplied was based on previous studies (Robert, Miner \& Nicolas 1996); whereas, the highest intensity corresponded to that used for flat oyster larvae (Gonzalez Araya et al. 2012).

Larval mortality and growth were recorded every 2 days. Shell length was measured using image analysis (software Image SXM by the National Institutes of Health). Mortality corresponded to the total number of empty shells (translucent larval shell) in samples of 300 larvae. Phytoplankton concentration was determined in $\mu \mathrm{m}^{3} \mu \mathrm{l}^{-1}, 24(12 \mathrm{dpf})$ and 72 (14 dpf) hours following aeration exposure, in all tanks, by means of an electronic particle counter (Multisizer 3 - Beckman) equipped with a $100 \mu \mathrm{m}$ aperture and a size range of 2-20 $\mu \mathrm{m}$. Larval feeding was expressed as clearance rate $\left(\%\right.$ day $\left.^{-1}\right)$ corresponding to the percentage of total algal ration daily consumed. Positive results will represent efficient microalgae consumption; whereas negative values will denote low food intake, lower than microalgal growth.

Scallop larval mortality has been often associated to the development of Vibrios such as $V$. pectenicida in Pecten maximus (Lambert, Nicolas, Cilia \& Corre 1998), V. splendidus in 
Argopecten purpuratus (Rojas, Miranda, Opazod \& Romerod 2015), V. alginolyticus in Argopecten ventricosus (Sainz, Maeda-Martinez \& Ascencio 1998) and we accordingly paid attention to its potential development. The percentage of Vibrio in total bacteria flora of larvae was thus recorded at 19 dpf using plate counting method on previously crushed larvae, with thiosulfate-citrate-bile salts-sucrose medium for Vibrio culture and marine agar for total flora (Azandegbe 2010).

At $17 \mathrm{dpf}, 50000$ larvae $(\approx 50 \mathrm{mg}$ wet weight minimum regardless to ontogenic stage) were collected on a $20-\mu \mathrm{m}$ mesh and stored at $-80^{\circ} \mathrm{C}$. Samples were weighted and homogenised in a Tris $\mathrm{HCl}$ buffer ( $\mathrm{pH}$ 7.4) as described in Guévélou, Huvet, Galindo-Sánchez, Milan, Quillien, Daniel, Quéré, Boudry \& Corporeau (2013). Total protein extraction was performed using an Ultra-Turax (Kinematica Kriens-Lu) in an ice-bath followed by a centrifugation at $15000 \mathrm{~g}$ during 20 min at $4^{\circ} \mathrm{C}$. Total protein amount was obtained using a DC protein assay (BIO RAD) using bovine serum albumin as standard in a microplate reader (Bio-Tek Synergy) as well as KC4 version 3 software (Bio-Tek Instrument Inc.). The activity of the three enzymes were analysed with the same microplate reader and software as protein content analyses, by applying a suitable program. Briefly, CAT (EC 1.11.1.6) activity was determined using the AmplexrRed Catalase Assay Kit (Invitrogen, USA) according protocol of the manufacturer measuring the decrease of absorbance at $240 \mathrm{~nm}$, due to $\mathrm{H}_{2} \mathrm{O}_{2}$ consumption. Total SOD (EC 1.15.1.1) activity was assessed with a SOD determination kit (Sigma-Aldrich) according to the manufacturer protocol using the absorbance at $450 \mathrm{~nm}$ after $30 \mathrm{~min}$ incubation at $37^{\circ} \mathrm{C}$. CS (EC 4.1.3.7) activity was obtained using the method of Childress and Somero (1979) by measuring the absorbance at $412 \mathrm{~nm}$ during $10 \mathrm{~min}$. 


\section{Impact of water flow}

In this experiment, larvae underwent the same treatment as that described above until $10 \mathrm{dpf}$. After sieving, larvae were distributed, at 10 larvae $\mathrm{ml}^{-1}$, in four triplicate treatments, in $50 \mathrm{~L}$ flowthrough tanks. Rectangular flat bottom units with low surface on volume ratio $(=0.196)$ were used with banjo mesh screens water outlet (Andersen, Christophersen \& Magnesen 2011) to prevent loss of larvae. The screen size was adjusted as the larvae grew, with an $80 \mu \mathrm{m}$ screen replaced to a $100 \mu \mathrm{m}$ screen on day 15 . In such tanks, larval survival at pediveliger stage reached $75.7 \pm 5.4 \%$ with $29.2 \pm 0.8 \%$ of competent larvae (unpublished results of a previous trial). Treatment " 0 " corresponded to an absence of water inflow (water being totally renewed each second day at once), “ $1 / 4$ " corresponded to water flow of $25 \%$ of the tank volume per hour (12.5 1 $\left.\mathrm{h}^{-1}\right)$ “ $1 / 2$ " to $50 \%\left(25 \mathrm{l} \mathrm{h}^{-1}\right)$ and " $1 / 4+$ air" to a water flow of $25 \%$ of the tank volume per hour plus

aeration at $300 \mathrm{ml} \mathrm{min}{ }^{-1}$. Induced by the same system set up in the first experiment, a similar high aeration condition was applied.

On 17 and 22 dpf, mortality and shell length were recorded as described above. At 22 dpf, the criterion of double ring appearance at the margin of the shell was used to estimate metamorphosis competence (number of larvae ready for metamorphosis: Gérard, Salaun \& Tritar 1989). The percentage of Vibrio in total bacteria flora was recorded during the whole experiment, as already described. At $17 \mathrm{dpf}$, larvae were sampled to quantify their total protein content and enzymatic activities of CAT, SOD and CS.

\section{Statistical analyses}

Permutational Analyses of Variances (PERMANOVA - PRIMER-E 6.0 PERMANOVA plus; PRIMER-E Ltd, Plymouth, UK) were preferred to ANOVAs, as it can be used on non-normal data generally recorded in larval rearing trials. If significant, posteriori comparisons were done using a PERMANOVA pairwise test to identify differences among treatment. When t-Tests were 
necessary, they were performed using the software R (2012) following Shapiro-Wilk normality test except for not normal data for which Wilcoxon-Mann-Whitney tests were used.

In aeration experiment, larval mortality, growth, and microalgal consumption were analyzed with a univariate one-way PERMANOVAs (9999 permutations), based on Euclidean resemblances. The independent variable in the PERMANOVAs was "aeration" with 4 fixed levels $0,100,150$ and $270 \mathrm{ml} \mathrm{m}^{-1}$. Larval mortality was detailed on $21 \mathrm{dpf}$; whereas, growth was and bacterial load studied two days preceeding mortalities, on 19 dpf. Food consumption was examined at 12 and $15 \mathrm{dpf}$ ( 24 and $72 \mathrm{~h}$ after aeration application) separately in an one-way PERMANOVA as homoscedasticity was not achieved for the factor "time" in the two-way crossed PERMANOVA $\left(\mathrm{p}_{(\mathrm{PERMDISP})}=0.032\right)$. CAT, SOD and CS activities were compared using one-way PERMANOVAs, with "aeration" as a source of variation.

In water flow experiment univariate one-way PERMANOVAs (9999 permutations) were used to evaluate the impact of flow rate on larval survival, growth, and bacterial contamination at $17 \mathrm{dpf}$. The independent variable was "flow rate" with three fixed levels $(0,1 / 4,1 / 2)$. The same PERMANOVAs were used for each of the three enzyme activities measurements. As all larvae, reared in treatment without flow rate $(0)$, died before $22 \mathrm{dpf}$, t-tests were only applied to larval mortality, growth, competency, and bacterial contamination for $1 / 4$ and $1 / 2$ treatments. T-tests were also used to compare $1 / 4$ and $1 / 4+$ air treatments for larval mortality, growth, Vibrio contamination, and enzymatic activities. 


\section{Results}

\section{Impact of aeration}

On $21 \mathrm{dpf}$, aeration significantly impacted larval survival $\left(\mathrm{p}=0.0007\right.$, Pseudo- $\left.\mathrm{F}_{(3-11)}=37.7\right)$. Larvae reared at the higher aeration intensity $\left(270 \mathrm{ml} \mathrm{min}^{-1}\right)$ exhibited severe mortality, $74.1 \pm 2.9 \%$ (Fig. 1), significantly different from others treatments with values $\leq 40 \%$ (270 vs 0 : $\mathrm{p}_{(\mathrm{MC})}=0.0001, \mathrm{t}=24.02 ; 270$ vs 100: $\mathrm{p}_{(\mathrm{MC})}=0.012, \mathrm{t}=4.44 ; 270$ vs 155: $\mathrm{p}_{(\mathrm{MC})}=0.0018$, $\mathrm{t}=7.53)$. The two other aeration treatments $\left(155 \mathrm{ml} \mathrm{min}^{-1}\right.$ and $\left.100 \mathrm{ml} \mathrm{min}^{-1}\right)$ led to statistically similar mortalities $\left(\mathrm{p}_{(\mathrm{MC})}=0.7, \mathrm{t}=0.40\right)$, with an overall mean of $37.5 \pm 1.8 \%$ (Fig. 1). Control treatments displayed the lowest mortalities with $3.7 \pm 0.5 \%$ (Fig. 1) that remained as low until 25 dpf. In contrast, all larvae exposed to the highest aeration $\left(270 \mathrm{ml} \mathrm{min}^{-1}\right)$ died on $23 \mathrm{dpf}$; whereas, those exposed to intermediate aerations (100 and $155 \mathrm{ml} \mathrm{min}^{-1}$ ) collapsed on $25 \mathrm{dpf}$. At $19 \mathrm{dpf}$, no Vibrios were detected over the whole experiment and no significant differences in bacterial load were observed $\left(\mathrm{p}=0.84\right.$ Pseudo-F $\left._{(3-32)}=0.41\right)$ with an overall mean of $336.4 \pm 95.7 \mathrm{CFU}$ larva $^{-}$ 1.

Larvae reared in still water (i.e. control condition) exhibited positive microalgae consumption (between 8 to $25 \%$ of microalgae consumption per day equivalent to $37811 \pm 9390$ to $157283 \pm$ 13432 cells eaten per larvae); whereas, larvae exposed to aeration registered negative consumption (Fig. 2). That means that in aerated treatments larval food consumption was lower than microalgal growth. Thus, aeration significantly depressed larval food intake, regardless to its intensity (24h: $\mathrm{p}=0.0001$, Pseudo- $\mathrm{F}_{(3-35)}=51.1 ; 72 \mathrm{~h}: \mathrm{p}=0.0001$, Pseudo- $\left.\mathrm{F}_{(3-23)}=98.3\right)$.

When exposed to aeration, larval growth was depressed (Fig. 3) but no significant differences were detected as regard to aeration levels $(100$ vs $155: \mathrm{p}=0.12, \mathrm{t}=1.63 ; 100$ vs $270: \mathrm{p}=0.20$, $\mathrm{t}=1.36 ; 155$ vs $270: \mathrm{p}=0.91, \mathrm{t}=0.12)$. On $19 \mathrm{dpf}$, larval lengths ranged from $169.7 \mu \mathrm{m} \pm 0.5$ to $173.5 \pm 0.7 \mu \mathrm{m}$, corresponding to a daily growth of $\approx 1 \mu \mathrm{m} \mathrm{d}^{-1}$. In contrast, larvae reared in still 
water were statistically larger than those submitted to aeration $(0$ vs 100: $\mathrm{p}=0.0001, \mathrm{t}=8.35$; 0 vs 155: $\mathrm{p}=0.0001, \mathrm{t}=11.69 ; 0$ vs 270: $\mathrm{p}=0.0002, \mathrm{t}=9.68)$ and exhibited a mean length of $185.7 \mu \mathrm{m} \pm 1.0$, corresponding to a daily growth of about $3.3 \mu \mathrm{m} \mathrm{d}^{-1}$.

On the other hand, when considering antioxidant defenses and specifically CAT activity, larvae reared in still water or exposed to the lowest aeration intensity $\left(100 \mathrm{ml} \mathrm{mn}^{-1}\right)$ exhibited similar results $\left(\mathrm{p}_{(\mathrm{MC})}=0.41, \mathrm{t}=0.9\right)$ with an overall mean of $88.5 \pm 2.3 \mathrm{U} \mathrm{mg}$ of protein ${ }^{-1}$ (Table 1). For the two highest aeration exposures, larval CAT activities were similarly depressed $\left(p_{(M C)}=0.52, t=0.68\right)$ with an overall mean of $63.5 \pm 1.2 \mathrm{U} \mathrm{mg}$ of protein ${ }^{-1}$ (Table 1$)$. Likewise, SOD activity of larvae, exposed to low and intermediate aerations (100 and $\left.155 \mathrm{ml} \mathrm{m}^{-1}\right)$, were close to control $\left(0\right.$ vs 100: $\mathrm{p}_{(\mathrm{MC})}=0.06, \mathrm{t}=2.7 ; 0$ vs $155: \mathrm{p}_{(\mathrm{MC})}=0.26, \mathrm{t}=1.3 ; 0$ vs 270 : $\mathrm{p}_{(\mathrm{MC})}=0.09, \mathrm{t}=2.3$ ) with an overall mean of $3.8 \pm 0.4 \mathrm{U} \mathrm{mg}$ of protein ${ }^{-1}$ (Table 1$)$. In contrast, larvae submitted to the highest aeration value $\left(270 \mathrm{ml} \mathrm{mn}^{-1}\right)$ showed significant lower SOD activities compared to the two other aeration intensities $(270 v s 100: \mathrm{p}=0.0063, \mathrm{t}=5.6$ and 270 vs 155: $\mathrm{p}=0.0098, \mathrm{t}=4.3$ - Table 1$)$.

Finally, on $17 \mathrm{dpf}$, CS activities were different between all larvae reared with aeration (100 vs 155: $\mathrm{p}_{(M C)}=0.0006, \mathrm{t}=9.4 ; 100$ vs 270: $\mathrm{p}_{(M C)}=0.004, \mathrm{t}=6.05 ; 155$ vs $270: \mathrm{p}_{(M C)}=0.02, \mathrm{t}=4.1-$ Table 1). The highest value was recorded in larvae exposed to $155 \mathrm{ml} \mathrm{mn}^{-1}$ aeration with $10.8 \pm 0.5 \mathrm{mU} \mathrm{mg}$ of $\operatorname{protein}^{-1}$.

\section{Impact of water flow and aeration in flow through-system}

After seven days of flow through rearing, the intensity of water renewal led to weak effects on larval performance (Table 2). On $17 \mathrm{dpf}$, larvae from all treatments $(0,1 / 4,1 / 2)$ showed similar survival $\left(\mathrm{p}=0.57\right.$, Pseudo- $\left.\mathrm{F}_{(2-8)}=0.60\right)$, with a mean of $58.03 \pm 2.43 \%$. Growth was slightly lower at higher water flow renewal $\left(\mathrm{p}_{(\mathrm{MC})}=0.008\right.$, Pseudo- $\left.\mathrm{F}_{(2-8)}=11.1\right)$, with larvae growing 1.3 times slower $\left(1 / 2\right.$ vs $\left.0: \mathrm{p}_{(\mathrm{MC})}=0.015, \mathrm{t}=4.0 ; 1 / 2 \mathrm{vs} 1 / 4: \mathrm{p}_{(\mathrm{MC})}=0.04, \mathrm{t}=2.9\right)$. The ratio of Vibrio to 
total bacteria was 6.4 times higher in this treatment $\left(1 / 2\right.$ vs $0: p_{(M C)}=0.0004, t=13.26 ; 1 / 2$ vs $1 / 4$ : $\left.\mathrm{p}_{(\mathrm{MC})}=0.003, \mathrm{t}=6.86\right)$ with a total bacterial load of $1048 \pm 296 \mathrm{CFU}$. In contrast, larval growth and percentages of Vibrio were similar between 0 and $1 / 4$ water renewal $\left(\right.$ growth: $\mathrm{p}_{(\mathrm{MC})}=0.13, \mathrm{t}=$ 1.9; Vibrio: $\mathrm{p}_{(\mathrm{MC})}=1, \mathrm{t}=5.47 \times 10^{-4}$ ), with respective means of $5.9 \pm 0.2 \mu \mathrm{m} \mathrm{d}^{-1}$ and $1.98 \pm 0.68 \%$, despite total bacteria loads at $1 / 2$ and 0 conditions reaching $952 \pm 521 \mathrm{CFU}$ and $7001 \pm 6002$ CFU respectively. Considering larval enzyme activities measured on 17 dpf (Fig. 4), no significant differences between treatments were registered $\left(\mathrm{CAT}: \mathrm{p}=0.07, \mathrm{PF}_{(2-8)}=3.49\right.$; SOD: $\left.\mathrm{p}=0.13, \mathrm{PF}_{(2-8)}=3.59 ; \mathrm{CS}: \mathrm{p}=0.08, \mathrm{PF}_{(2-8)}=4.68\right)$.

On 22 dpf, only larvae reared in flow-through system survived with no significant differences in larval performances due to the intensity of water renewal (Table 2). Performances of larvae reared in flow-through $(1 / 2$ and $1 / 4)$ were similar for survival $(\mathrm{p}=0.85, \mathrm{t}=0.2$; mean $=$ $20.4 \pm 0.5 \%)$, growth $\left(\mathrm{p}=0.93, \mathrm{t}=0.096 ;\right.$ mean $\left.=3.8 \pm 0.2 \mu \mathrm{m} \mathrm{d}^{-1}\right)$, competence $(\mathrm{p}=0.93$, $\mathrm{t}=0.098 ;$ mean $=5.6 \pm 0.2 \%)$ and relative Vibrio concentration with a mean of $0.6 \pm 0.2 \%$ and $\mathrm{a}$ total bacterial load of $800 \pm 256 \mathrm{CFU}(\mathrm{p}=0.45, \mathrm{t}=8.84)$.

The impact of aeration on performances of larvae reared in flow through $(1 / 4$ vs $1 / 4+$ air $)$ is reported in Table 3. On $17 \mathrm{dpf}$, survival was similar regardless of experimental conditions $(\mathrm{p}=0.41, \mathrm{t}=0.92)$. However, larvae reared without aeration grew 1.4 times faster $(\mathrm{p}=0.002$, $\mathrm{t}=6.83)$ and Vibrio were 3.4 times less abundant $(\mathrm{p}=0.047, \mathrm{t}=2.84)$. On the other hand, SOD activities were similar $(\mathrm{p}=0.36, \mathrm{t}=1.02)$ between treatments, with a mean of $1.7 \pm 0.2 \mathrm{U} \mathrm{mg} \mathrm{protein}^{-1}$, but CAT activity showed significant differences, with values 2.7 times higher $(\mathrm{p}=0.008, \mathrm{t}=4.8)$ in larvae reared without aeration (Fig. 4). Lastly, CS activity was 1.7 times higher $\left(\mathrm{p}=4.8 \times 10^{-5}, \mathrm{t}=18.7\right)$ in larvae reared with aeration (Fig. 4$)$, which all died before the end of the experiment. In flow-through system and in presence of aeration, all larvae died 
before reaching the pediveliger stage. Without aeration survival and competence reached $21.0 \pm$ $8.5 \%$ and $5.8 \pm 2.6 \%$ respectively.

\section{Discussion}

The objective of this study was to document how physical factors may impact Pecten maximus larval development in order to improve pectinid hatchery production systems. Our results clearly showed that aeration, even at low flow, decreases rearing performances and physiological larval conditions regardless of the rearing system, static or flow-through. However, water renewal (without any aeration) in rectangular flat-bottomed tank do not impact larval development and limit Vibrio load. This system demonstrated, thus, its ability to produce pectinid larvae until metamorphosis in small tanks of $50 \mathrm{~L}$.

\section{Impact of aeration}

In contrast to still water, microalgal intake of larvae exposed to aeration was lower than microalgal growth $24 \mathrm{~h}$ after the onset of the experiment regardless of bubbling intensity. Aeration swiftly impeded larvae to feed normally. The absence of microalgal consumption had a rapid and direct impact on larval growth. Gregg \& Bergersen (1980) reported that turbulence increased the mortality of the shrimp Mysis relicta. They suggested that abrasion and exhaustion due to continuous swimming and inability to feed could be the principal causes of the mortality observed. Scanning electron microscopy examinations of eventual mechanical abrasive impact on scallop larvae remain to be done to explore this hypothesis. On the other hand, zebra mussel larvae withstand greater aeration because $40 \%$ survival was recorded at $5 \mathrm{~L} \mathrm{ml}^{-1}$ airflow (Rehmann, Stoeckel \& Schneider 2003). Moreover, Helm \& Spencer (1972) showed that aeration improve growth and development of eyespot in European flat oyster larvae. Similarly, settlement

of Potamocorbula amurensis (Crimaldi, Thompson, Rosman, Lowe \& Koseff 2002), Mytilus 
edulis (Pernet, Tremblay \& Bourget 2003b) and Ilyanassa obsolete (Fuchs, Mullineaux \& Solow 2004) was also improved with aeration. This pattern has been proposed as an adaptation to disperse and settle more successfully in highly turbulent and energetic coastal regions (Fuchs \& DiBacco 2011). P. maximus appears to react differently, as in the present study, larvae died in presence of aeration, regardless to rearing system, sequential or flow-through system. Oysters and mussels mainly live in intertidal zones exposed to substantial short-term environmental variations (Gosling 2008); whereas, pectinids live in subtidal areas, subject to more stable environment (Brand 2006 and references therein). Great scallop are usually found in extreme low tide down to $250 \mathrm{~m}$ and are known to be more abundant far away of high water streams (Brand 2006). This could be a partial explanation of the sensitivity of pectinid larvae (Helm, Bourne \& Lovatolli 2004) and confirm the necessity to adapt zootechnical procedure for scallop larval rearing.

The rise of CS activity in larvae exposed to aeration in the present experiments (static and flow-through systems) could be a sign of an increased metabolic rate in a turbulent stressful environment. Positive correlation between respiration and CS activity has been previously demonstrated in bivalves (Moran \& Manahan 2004 ; Meyer, Green, Moore \& Manahan 2007). This correlation as well as the high energetic metabolism recorded here suggest that larvae swim endlessly until lethal exhaustion. Thus, an increase in ATP production could result in a higher energy demand to support additional efforts to swim due to a turbulent environment (Gregg \& Bergersen 1980). Since larval size was lower in all treatments including aeration, the increased metabolic rate did not seem to be sufficient to provide more energy to swim without impacting larval growth. In contrast, Genard et al. (2011) and Genard, Miner, Nicolas, Moraga, Boudry, Pernet \& Tremblay (2013) reported a decrease of CS activity in oyster larvae during a stresfull event. However, in these studies focused on exposition of larvae to bacterial pathogen, the CS 
decrease corresponded to a different behavior consisting in larval shell closure followed by sinking.

In both our conditions with aeration, SOD activity remained constant; whereas, CAT activity was either stable or decreased, suggesting that antioxidant defences were inactivated. In our flowthrough system, this phenomenon coupled to the high proportion of Vibrio detected in larvae exposed to aeration, is likely to be a consequence rather than the cause of the observed high number of moribund larvae.

\section{Impact of water flow}

In flat-bottomed flow-through tank without any aeration, enzyme activities, used as indicators of physiological stress, did not suggested stressful responses of scallop larvae, as no clear trend in the three enzymes activities studied was observed.

Rearing scallop larvae without any antibiotic is generally performed in large volume tanks (>500 L) to avoid mass mortality (Campa-Cørdova, Luna-GonzaLez, Zarain-Herzberg \& Caceres-Martinez 2005 ; Magnesen, Bergh \& Christophersen 2006 ; Merino, Uribe, Soria \& von Brand 2009 ; Pernet, Tremblay \& Bourget 2003a). Volumes tested varied from 500 to 4700 L with densities ranging from 1.5 to 13 larvae $\mathrm{ml}^{-1}$ (Magnesen et al. 2006 ; Torkildsen \& Magnesen 2004). In the present study, the use of flat-bottomed tanks led to acceptable scallop larval development performances with $20.4 \pm 0.5 \%$ survival and $5.6 \pm 0.2 \%$ competence in small tank volume of only $50 \mathrm{~L}$. The ratio surface to volume has been suggested to be important for P. maximus larval rearing and need to be as low as possible to allow successful larval development (Helm, Bourne \& Lovatolli 2004). The 50 L flat-bottomed tanks used in our study had a surface on volume ratio of 0.196 which might explain this relative rearing achievement compared to the $5 \mathrm{~L}$ cylindrical tanks that exhibited a surface on volume ratio of 0.585 and previously led to unsuccessful results (Holbach 2015). 
No significant variations were observed in CS enzyme activities between the three conditions tested $(0,1 / 4,1 / 2)$ suggesting that ATP demand was similar until mortality occurred (Moran \& Manahan 2003). Indeed, no clear establishment of antioxidant defences was noted at $17 \mathrm{dpf}$, as SOD and CAT activities did not increase (Genard et al. 2013). On $17 \mathrm{dpf}$, the high proportion of Vibrio observed in $1 / 2$ flow-through seawater renewal was surprising because it reached similar values than in the $1 / 4$ condition, five days later $(22 \mathrm{dpf})$ without any of mortality. This might result in external contamination of the samples. On the other hand, the lower growth recorded in those larvae could be related to high water movement and the inability of larvae to feed efficiently as discussed above. However, consumption was difficult to measure in this system and we could not validate this hypothesis.

\section{Conclusion}

In our study, we showed how hydrodynamic factors (aeration and flow through) impact scallop larval development. Aeration was clearly detrimental for scallop larvae in contrast to the intensity of water renewal. The water flow needs to be adjusted in order to optimize environment homogenization without disturbing larval natural behavior. The results that seemed to be related to the physiological needs of this species and ecological niche, bring useful information for future application in aquaculture production. The flat-bottomed tanks of $50 \mathrm{~L}$ led to encouraging larval development performances but further investigations are needed to confirm such results, in particular with higher larval densities. The optimization of this rearing system needs to be settled, with compromise between production costs (microalgal production and water warming) and yield of competent larvae. 


\section{Acknowledgements}

The authors would like to thank the Tinduff hatchery for providing scallop larvae as well as the technical team of Ifremer facilities in Argenton, - Isabelle Quéau and Luc Lebrun for algal production; and Claudie Quéré and Catherine Séguineau for their assistance for enzymatic analyses. We are also grateful to the "Ministère du Développement Economique, de l'Innovation et de l'Exportation du Québec" (MDEIE), which contributed to the funding of a Ph.D. scholarship, to "Ressource Aquatiques Québec" (RAQ), and to "Fonds de Recherches du Québec - Nature et technologies" (FRQNT), which provided travel grant to Marine Holbach. This work was carried out during the EU funded project ReproSeed (FP7-KBBE-2009-3), which partly supported functional outlays.

\section{References}

Andersen S., Christophersen G. \& Magnesen T. (2011) Spat production of the great scallop (Pecten maximus): a roller coaster11. Canadian Journal of Zoology 89, 579-598.

Andersen S., Christophersen G. \& Magnesen T. (2012) Implications of larval diet concentration on post-larval yield in a production scale flow-through system for scallops (Pecten maximus ; Lamarck) in Norway. Aquaculture International 21, 435-452.

Azandegbe A. (2010) Study of sediment bacterial communities' structure and ecology of Vibrio aestuarianus pathogen of the oyster Crassostrea gigas in two oyster culture sites. $\mathrm{PhD}$, Université Européenne de Bretagne, Brest, 256pp.

Bergh Ø. \& Strand Ø. (2001) Great scallop, Pecten maximus, research and culture strategies in Norway: a review. Aquaculture International 9, 305-317. 
Brand A.R. (2006) Chapter 12: Scallop ecology: Distributions and behaviour. In: Scallops : Biology, Ecology and Aquaculture (ed. by Shumway SE, Parsons JG). Elsevier, pp. 651744.

Brokordt K., Núñez G. \& Gaymer C. (2011) Improving escape responses of hatchery-reared scallops Argopecten purpuratus. Marine Biology 158, 1311-1318.

Buestel D. (1979) The exploitation of the Patinopecten yessoensis in Japan - Application opportunities of the Japanese development model to the French Pecten maximus $\mathrm{L}$. species. Journées d'étude "Aquaculture extensive et repeuplement". CNEXO, Actes de colloques $n^{\circ} 12,15-32$.

Calabrese A. \& Davis H.C. (1970) Tolerances and requirements of embryos and larvae of bivalve molluscs. Helgoländer wissenschaftliche Meeresuntersuchungen 20, 553-564.

Campa-Cørdova A.I., Luna-GonzaLez A., Zarain-Herzberg M. \& Caceres-Martinez C.J. (2005) Prophylactic use of antibiotics in larval culture of Argopecten ventricosus (Sowerby, 1835). Journal of Shellfish Research 24, 923-930.

Childress J.J. \& Somero G.N. (1979) Depth-related enzyme activities in muscle, brain and heart of deep-living pelagic marine teleosts. Marine Biology 52, 272-283.

Crimaldi J.P., Thompson J.K., Rosman J.H., Lowe R.J. \& Koseff J.R. (2002) Hydrodynamics of larval settlement: the influence of turbulent stress events at potential recruitment sites. Limnology and Oceanography 47, 1137-1151.

Da Costa F., Petton B., Mingant C., Bougaran G., Rouxel C., Quéré C., Wikfors G.H., Soudant P. \& Robert R. (2015) Influence of one selected Tisochysis lutea strain rich in lipids on Crassostrea gigas larval development and biochemical comoposition. Aquaculture Nutrition 22, 1-24. 
FAO Fisheries and Aquaculture Information and Statistics Service, 2013. Aquaculture production 1950-20013. FISHSTAT Plus - Universal software for fishery statistical time series [online or CD-ROM]. Food and Agriculture Organization of the United Nations. Available at: http://www.fao.org/fishery/statistics/software/fishstat/en.

Fuchs H.L. \& DiBacco C. (2011) Mussel larval responses to turbulence are unaltered by larval age or light conditions. Limnology \& Oceanography: Fluids \& Environments 1, 120-134.

Fuchs H.L., Mullineaux L.S. \& Solow A.R. (2004) Sinking Behavior of Gastropod Larvae (Ilyanassa obsoleta) in Turbulence. Limnology and Oceanography 49, 1937-1948.

Genard B., Laroucher O., Nicolas J.L., Miner P., Beaudin M.-L. \& Tremblay R. (2014) Effect of the probiotic strain Phaeobacter gallaeciensis (X34) after bacterial challenge on the complete larval development of Pecten maximus. Aquatic Living Resources 27, 27-34.

Genard B., Miner P., Nicolas J.-L., Moraga D., Boudry P., Pernet F. \& Tremblay R. (2013) Integrative Study of Physiological Changes Associated with Bacterial Infection in Pacific Oyster Larvae. PLoS ONE 8, e64534.

Genard B., Pernet F., Lemarchand K., Boudry P., Moraga D. \& Tremblay R. (2011) Physiological and biochemical changes associated with massive mortality events occurring in larvae of American oyster (Crassostrea virginica). Aquatic Living Resources 24, 247-260.

Gérard A., Salaun M. \& Tritar S. (1989) Critères de compétence des larves à la métamorphose chez Pecten maximus. Haliotis 19, 373-380.

Gonzalez Araya R., Mingant C., Petton B. \& Robert R. (2012) Influence of diet assemblage on Ostrea edulis broodstock conditioning and subsequent larval development. Aquaculture 364, 272-280. 
Gosling E. (2008) Bivalve molluscs: biology, ecology and culture, Great Britain, John Wiley \& Sons, $456 \mathrm{pp}$.

Gregg R.E. \& Bergersen E.P. (1980) Mysis relicta: Effects of turbidity and turbulence on shortterm survival. Transactions of the American Fisheries Society 109, 207-212.

Gruffydd L.D. \& Beaumont A.R. (1972) A method for rearing Pecten maximus larvae in the laboratory. Marine Biology 15, 350-355.

Guévélou E., Huvet A., Galindo-Sánchez C.E., Milan M., Quillien V., Daniel J.-Y., Quéré C., Boudry P. \& Corporeau C. (2013) Sex-specific regulation of AMP-Activated Protein Kinase (AMPK) in the Pacific oyster Crassostrea gigas. Biology of Reproduction 89, Article 100, 101-115.

Holbach M. (2015) La sensibilité des larves de pectinidés aux conditions d'élevage : le flux ouvert comme alternative aux mortalités massives. PhD, Université de Bretagne Occidentale, $175 \mathrm{pp}$.

Helm M.M., Bourne N. \& Lovatelli A. (2004) Hatchery culture of bivalves. A practical manual. : Fisheries Technical Paper No.471. FAO, Rome, 200 pp.

Helm M.M. \& Spencer B.E. (1972) The importance of the rate of aeration in hatchery cultures of the larvae of Ostrea edulis L. Journal du Conseil 34, 244-255.

Kesarcodi-Watson A., Miner P., Nicolas J.-L., Asmani K. \& Robert R. (2014) Pathogenic threats and probiotic use in larviculture of the scallop, Pecten maximus. Aquaculture Research 47, $1221-1230$

Lambert C., Nicolas J.-L., Cilia V. \& Corre, S. (1998) Vibrio pectenicida sp. nov., a pathogen of scallop (Pecten maximus) larvae. International Journal of Systematic Bacteriology 48, 484-487. 
Magnesen T., Bergh O. \& Christophersen G. (2006) Yields of great scallop, Pecten maximus, larvae in a commercial flow through rearing system in Norway. Aquaculture International 14, 377-394.

Merino G., Uribe E., Soria G. \& von Brand E. (2009) A comparison of larval production of the northern scallop, Argopecten purpuratus, in closed and recirculating culture systems. Aquacultural Engineering 40, 95-103.

Meyer E., Green A.J., Moore M. \& Manahan D.T. (2007) Food availability and physiological state of sea urchin larvae (Strongylocentrotus purpuratus). Marine Biology 152, 179-191.

Moran A.L. \& Manahan D.T. (2003) Energy metabolism during larval development of green and white abalone, Haliotis fulgens and H. sorenseni. The Biological Bulletin 204, 270-277.

Moran A.L. \& Manahan D.T. (2004) Physiological recovery from prolonged 'starvation' in larvae of the Pacific oyster Crassostrea gigas. Journal of Experimental Marine Biology and Ecology 306, 17-36.

Pernet F., Tremblay R. \& Bourget E. (2003a) Biochemical indicator of sea scallop (Placopecten magellanicus) quality based on lipid class composition. Part II: Larval growth, competency and settlement. Journal of Shellfish Research 22, 377-388.

Pernet F., Tremblay R. \& Bourget E. (2003b) Settlement success, spatial pattern and behavior of mussel larvae Mytilus spp. in experimental 'downwelling' systems of varying velocity and turbulence. Marine Ecology Progress Series 260, 125-140.

Philipp E.E.R., Schmidt M., Gsottbauer C., Sanger A.M. \& Abele D. (2008) Size-and agedependent changes in adductor muscle swimming physiology of the scallop Aequipecten opercularis. Journal of Experimental Biology 211, 2492-2501.

Rehmann C.R., Stoeckel J.A. \& Schneider D.W. (2003) Effect of turbulence on the mortality of zebra mussel veligers. Canadian Journal of Zoology 81, 1063-1069. 
Robert R., Vignier J. \& Petton B., 2017. Influence of feeding and temperature on development and settlement of oyster Ostrea edulis (Lineaeus 1758) larvae. Aquaculture Research, 118, doi 10.11111/are.13297.

Robert R. \& Gérard A. (1999) Bivalve hatchery technology: The current situation for the Pacific oyster Crassostrea gigas and the scallop Pecten maximus in France. Aquatic Living Resources 12, 121-130.

Robert R., Miner P. \& Nicolas J.L. (1996) Mortality control of scallop larvae in the hatchery. Aquaculture International 4, 305-313.

Rojas R., Miranda C.D., Opazod R. \& Romerod J. (2015) Characterization and pathogenicity of Vibrio splendidus strains associated with massive mortalities of commercial hatcheryreared larvae of scallop Argopecten purpuratus (Lamarck, 1819). Journal of Invertebrate Pathology 124, 61-69.

Sainz J.C., Maeda-Martinez A.N. \& Ascencio F. (1998) Experimental vibriosis induction with Vibrio alginolyticus of larvae of the catarina scallop (Argopecten ventricosus $=$ circularis) (Sowerby II, 1842). Microbial Ecology 35, 188-192

Torkildsen L. \& Magnesen T. (2004) Hatchery production of scallop larvae (Pecten maximus) Survival in different rearing systems. Aquaculture International 12, 489-507.

Tremblay R., Cartier S., Miner P., Pernet F., Quéré C., Moal J., Muzellec M.-L., Mazuret M., Samain J.-F. (2007) Effect of Rhodomonas salina addition to a standard hatchery diet during the early ontogeny of the scallop Pecten maximus. Aquaculture 262, 410-418.

Widman J.C. Jr., Choromanski J., Robohm R.A., Stiles S., Wikfors, G.H. \& Calabrese. A. (2001) Manual for hatchery culture of the bay scallop, Argopecten irradians irradians. Connecticut Sea Grant College Program, CTSG-01-03., 50pp. 
Table 1: Activities of CAT (catalase), SOD (superoxide dismutase) and CS (citrate synthase), in Pecten maximus larvae exposed to four aeration levels (0,100, 155 and $\left.270 \mathrm{ml} \mathrm{min}{ }^{-1}\right), 17$ days post-fertilization (dpf). Data are expressed as units per mg of proteins. Data are mean \pm standard error. Different letters indicate significant differences for each enzyme studied.

\begin{tabular}{|c|c|c|c|c|}
\hline dpf & $\begin{array}{l}\text { Aeration intensity } \\
\quad\left(\mathrm{ml} \mathrm{min} \mathbf{m i n}^{-1}\right)\end{array}$ & $\begin{array}{c}\mathrm{CAT} \\
\left(\mathrm{U} \mathrm{mg}^{-1}\right)\end{array}$ & $\begin{array}{l}\text { SOD } \\
\left(\mathbf{U ~ m g}^{-1}\right)\end{array}$ & $\begin{array}{c}\mathrm{CS} \\
\left(\mathrm{mU} \mathbf{m g}^{-1}\right)\end{array}$ \\
\hline \multirow{4}{*}{17} & $\mathbf{0}$ & $84.3 \pm 4.2^{\mathrm{a}}$ & $3.8 \pm 0.4^{\mathrm{ab}}$ & $6.9 \pm 0.6^{b c}$ \\
\hline & 100 & $88.8 \pm 2.5^{\mathrm{a}}$ & $4.2 \pm 0.2^{\mathrm{a}}$ & $5.5 \pm 0.3^{c}$ \\
\hline & 155 & $64.8 \pm 3.3^{\mathrm{b}}$ & $4.5 \pm 0.4^{\mathrm{a}}$ & $10.8 \pm 0.5^{\mathrm{a}}$ \\
\hline & 270 & $62.3 \pm 1.4^{\mathrm{b}}$ & $2.8 \pm 0.2^{\mathrm{b}}$ & $8.3 \pm 0.4^{b}$ \\
\hline
\end{tabular}


Table 2: Survival, growth, competence and Vibrio on total flora load (V/FT) of Pecten maximus larvae reared in 50-L rectangular tanks, in flow through, at three different water flow renewal: 0 (no inflow), $12.5 \mathrm{~L} \mathrm{~h}^{-1}(1 / 4), 25 \mathrm{~L} \mathrm{~h}^{-1}(1 / 2), 17$ and 22 days post-fertilization (dpf). Data are mean \pm standard error; different letters indicate significant differences among treatments.

\begin{tabular}{|c|c|c|c|c|c|c|}
\hline dpf & $\begin{array}{c}\text { Volume of renewed } \\
\text { tank water } \mathbf{h}^{-1}\end{array}$ & $\begin{array}{l}\text { Survival } \\
(\%)\end{array}$ & $\begin{array}{l}\text { Growth } \\
\left(\mu \mathrm{m} \text { day }^{-1}\right)\end{array}$ & $\begin{array}{l}\text { Size } \\
(\mu \mathrm{m})\end{array}$ & $\begin{array}{l}\text { V/FT } \\
(\%)\end{array}$ & $\begin{array}{c}\text { Competence } \\
(\%)\end{array}$ \\
\hline \multirow{3}{*}{17} & $\mathbf{0}$ & $60.9 \pm 69^{\mathrm{a}}$ & $6.1 \pm 0.2^{\mathrm{a}}$ & $178.7 \pm 1.2^{\mathrm{a}}$ & $2.0 \pm 0.5^{\mathrm{b}}$ & - \\
\hline & $1 / 4$ & $60.0 \pm 4.2^{\mathrm{a}}$ & $5.6 \pm 0.2^{\mathrm{ab}}$ & $175.5 \pm 1.2^{\mathrm{ab}}$ & $2.0 \pm 1.4^{\mathrm{b}}$ & - \\
\hline & $1 / 2$ & $53.2 \pm 4.8^{\mathrm{a}}$ & $4.4 \pm 0.4^{\mathrm{b}}$ & $166.7 \pm 2.8^{b}$ & $12.7 \pm 1.0^{\mathrm{a}}$ & - \\
\hline \multirow{3}{*}{22} & $\mathbf{0}$ & 0 & 0 & 0 & 0 & 0 \\
\hline & $1 / 4$ & $21.0 \pm 8.5^{\mathrm{a}}$ & $3.8 \pm 0.2^{\mathrm{a}}$ & $175.5 \pm 1.2^{\mathrm{a}}$ & $0.8 \pm 0.4^{\mathrm{a}}$ & $5.8 \pm 2.6^{\mathrm{a}}$ \\
\hline & $1 / 2$ & $19.9 \pm 3.7^{\mathrm{a}}$ & $3.8 \pm 0.2^{\mathrm{a}}$ & $181.3 \pm 1.9^{\mathrm{a}}$ & $0.4 \pm 0.2^{\mathrm{a}}$ & $5.4 \pm 2.2^{\mathrm{a}}$ \\
\hline
\end{tabular}


Table 3: Survival, growth, competence and Vibrio as a percentage of total bacteria flora (V/FT) of Pecten maximus larvae reared in 50-L rectangular tanks, in flow through, at $12.5 \mathrm{~L} \mathrm{~h}^{-1}(1 / 4)$ water flow renewal and with or without aeration, 17 and 22 days post-fertilization (dpf). Data are mean \pm standard error; different letters indicate significant differences between treatments. No statistical analyses were done at day 22 since only one condition survived.

\begin{tabular}{|c|c|c|c|c|c|c|c|}
\hline dpf & $\begin{array}{c}\text { Volume of } \\
\text { renewed tank } \\
\text { water } h^{-1}\end{array}$ & $\begin{array}{l}\text { Aeration } \\
\left(\mathrm{ml} \mathrm{min}^{-1}\right)\end{array}$ & $\begin{array}{c}\text { Survival } \\
(\%)\end{array}$ & $\begin{array}{c}\text { Growth } \\
\left(\mu \mathrm{m} \text { day }^{-1}\right)\end{array}$ & $\begin{array}{l}\text { Size } \\
(\mu \mathrm{m})\end{array}$ & $\begin{array}{l}\text { V/FT } \\
(\%)\end{array}$ & $\begin{array}{c}\text { Competence } \\
(\%)\end{array}$ \\
\hline \multirow{2}{*}{17} & \multirow{2}{*}{$1 / 4$} & $\mathbf{0}$ & $60.0 \pm 4.2^{\mathrm{a}}$ & $5.6 \pm 0.2^{\mathrm{a}}$ & $175.5 \pm 1.2^{\mathrm{a}}$ & $2.0 \pm 1.4^{\mathrm{b}}$ & - \\
\hline & & 300 & $53.0 \pm 6.4^{\mathrm{a}}$ & $4.1 \pm 0.2^{\mathrm{b}}$ & $165.0 \pm 1.0^{\mathrm{b}}$ & $6.3 \pm 0.4^{\mathrm{a}}$ & - \\
\hline \multirow{2}{*}{22} & \multirow{2}{*}{$1 / 4$} & 0 & $21.0 \pm 8.5$ & $3.8 \pm 0.2$ & $175.5 \pm 1.2$ & $0.8 \pm 0.4$ & $5.8 \pm 2.6$ \\
\hline & & 300 & 0 & 0 & 0 & 0 & 0 \\
\hline
\end{tabular}




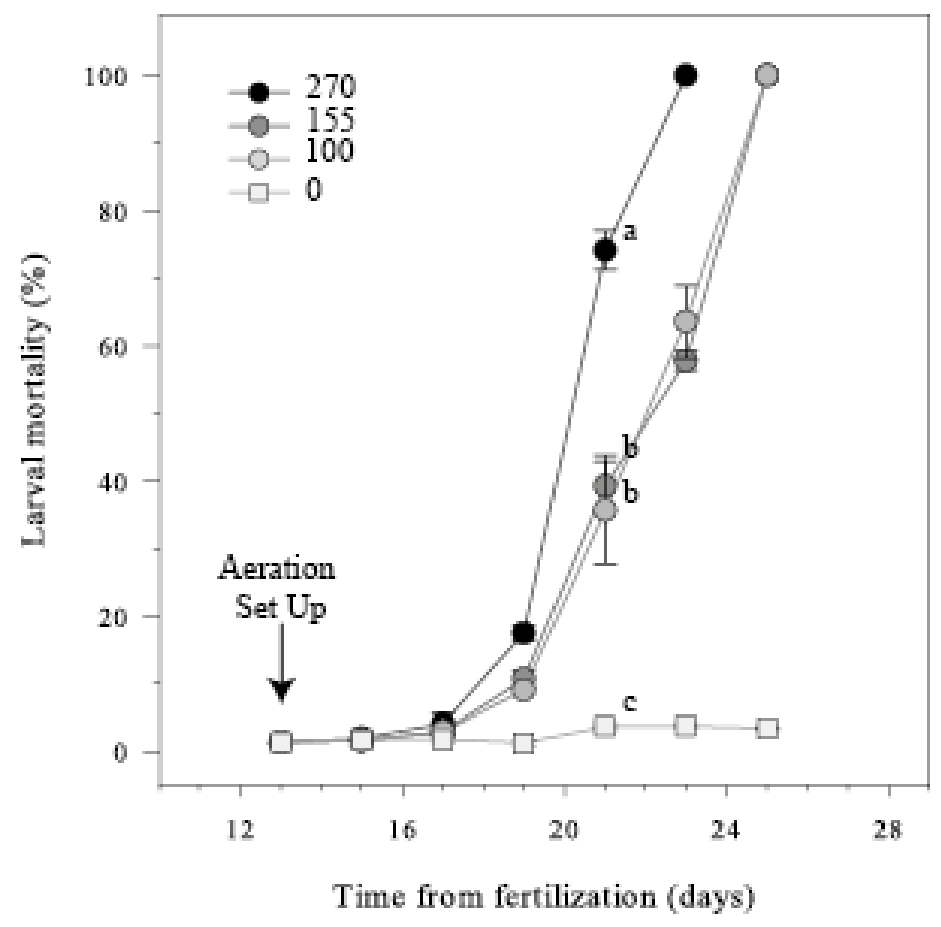

Figure 1: Evolution of mortalities in Pecten maximus larvae, exposed, from 13 days postfertilization (dpf), to four different aeration levels, $0,100,155$ and $270 \mathrm{ml} \mathrm{min}^{-1}$. Data are mean \pm standard error and are expressed in percentage. Different letters indicate significant differences measured on $21 \mathrm{dpf}$. 


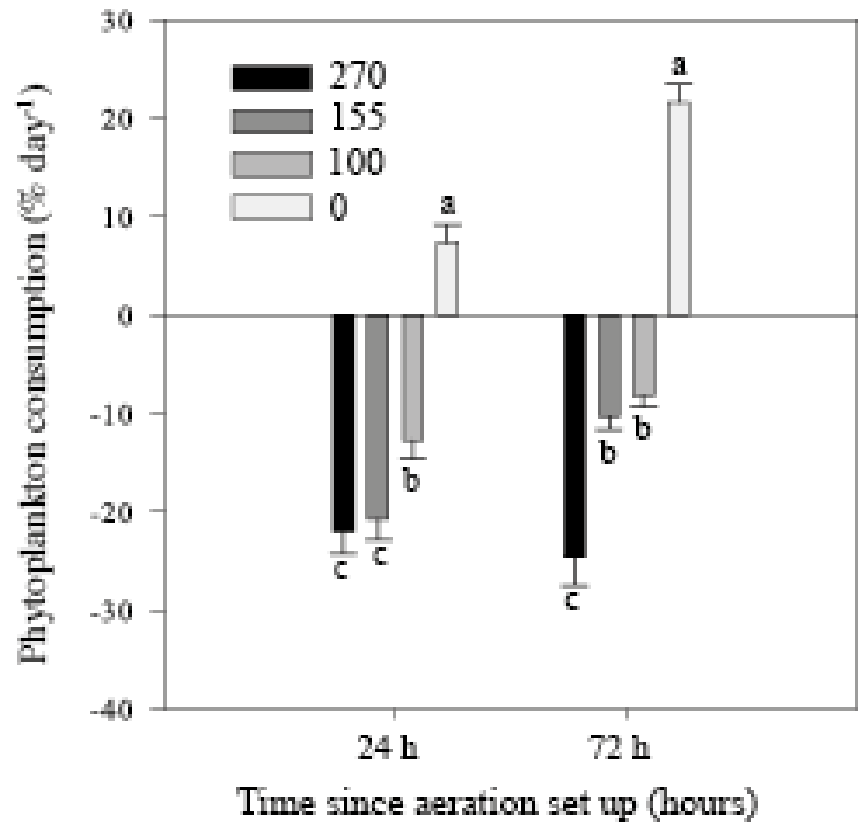

Figure 2: Food uptake of Pecten maximus larvae, exposed to four different aeration levels, 0, 100, 155 and $270 \mathrm{ml} \mathrm{min}^{-1}$, one and three days after aeration set up on 13 days post-fertilization (dpf). Data are mean \pm standard error and are expressed as percentages of food uptake per day. Different letters indicate significant differences. 


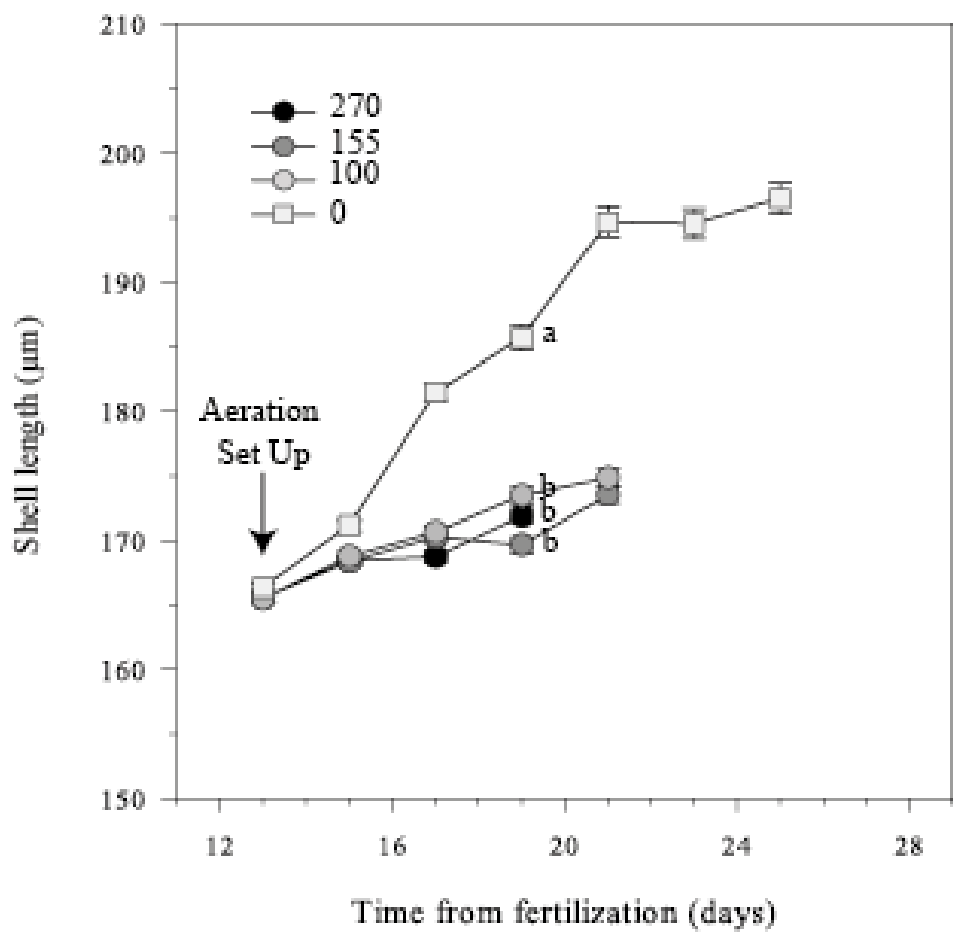

Figure 3: Evolution of shell length $(\mu \mathrm{m})$ in Pecten maximus larvae, exposed, from 13 days postfertilization (dpf), to four different aeration levels, $0,100,155$ and $270 \mathrm{ml} \mathrm{min}^{-1}$. Data are mean \pm standard error. Different letters indicate significant differences measured on $19 \mathrm{dpf}$. 

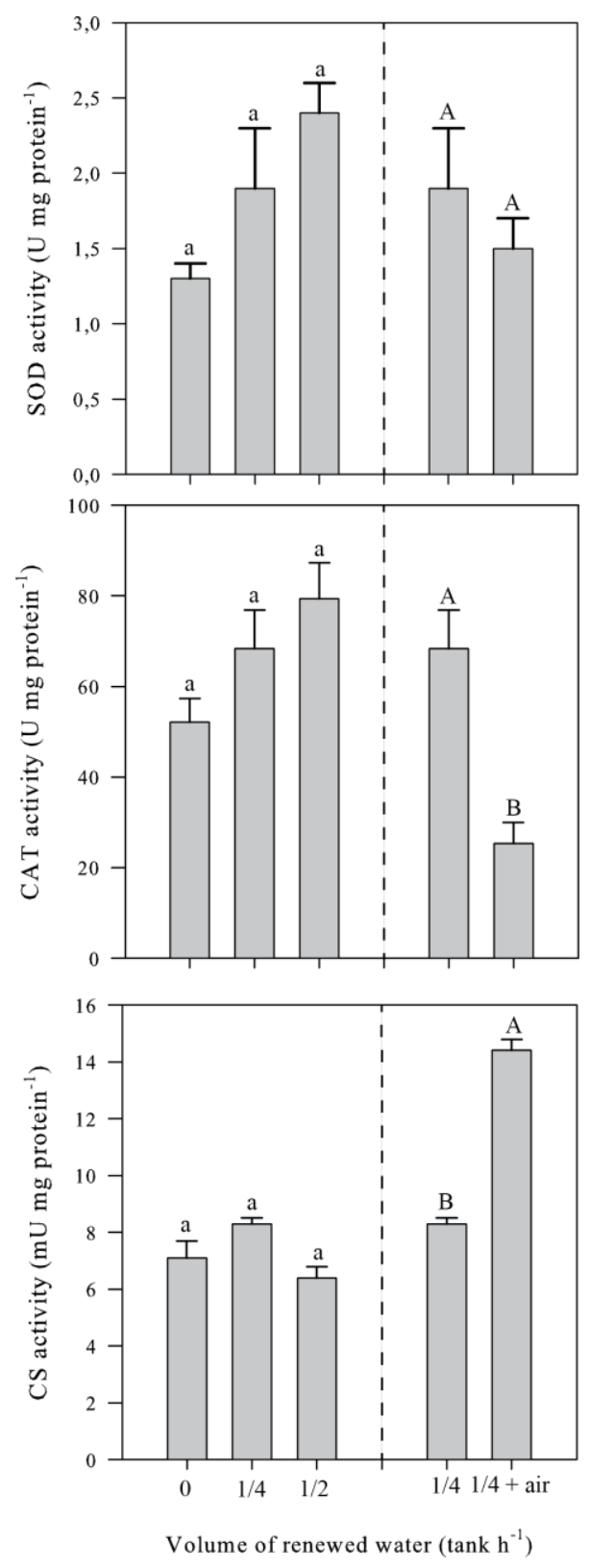

Figure 4: Enzymatic activities of superoxide dismutase (SOD - U mg protein ${ }^{-1}$ ), catalase (CAT - U mg protein ${ }^{-1}$ ), and citrate synthase (CS - mU mg protein $\left.{ }^{-1}\right)$ in Pecten maximus larvae reared in 50-L rectangular tanks, in flow through at three different levels of water flow renewal: 0 (no inflow), $12.5 \mathrm{~L} \mathrm{~h}^{-1}(1 / 4), 25 \mathrm{~L} \mathrm{~h}^{-1}$ (1/2) on 27 days post-fertilization (dpf). At $12.5 \mathrm{~L} \mathrm{~h}^{-1}$ seawater renewal an aeration of $300 \mathrm{ml} \mathrm{h}^{-1}$ was also implemented (1/4 + air). Data are mean \pm standard error 
and different letters indicate significant differences between flow-through treatments and between aeration treatments. 